\title{
Religious Identities and the Struggle for Secularism The Revival of Buddhism and Religions of Marginalized Groups in Nepal
}

\author{
DAVIDE TORRI \\ Universität Heidelberg, Germany
}

\begin{abstract}
One of the most relevant aspects of contemporary political life in Nepal is the rise of ethnic minorities. From the early 1990s, the movement for democracy started campaigning against Hindu Monarchic autocracy for the lifting of the ban on political parties, the recognition of multiculturalism and freedom of religion. Many things have changed since then: a Maoist-led insurgency and a new people's movement have managed to topple the monarchy and to transform the Himalayan country into a republic. As a reaction to the state-enforced Hinduization of the people, supporting the caste system and maintaining the power in the hands of high-caste Hindus, many groups are now campaigning to revive their local cultures and traditions. Religion is one of the key areas of confrontation, and the struggle for secularism has created space for the revival of the religious traditions of marginalized groups.
\end{abstract}

KEYWORDS Nepal, religion, secularism, indigeneity, marginalized groups, identity, Shamanism, Buddhism

\section{Introduction}

The struggle for secularism in contemporary Nepal is intrinsically tied to the major political developments of at least the last three decades. During this time, a sequence of events took place bringing about deep changes at almost every level. A list of those events should surely include the first jana andolan (people's movement) of 1990, a mass mobilization to re-establish parliamentary political life under monarchic rule. The jana andolan succeeded in forcing the then King, Birendra, to put an end to the panchayat system. This movement to restore democracy took direct inspiration from what happened in Eastern Europe in 1989. Shortly thereafter, in 1996, the insurrectionary factions of the left-wing political spectrum, under the guidance of the Communist Party of Nepal (Maoist), started a guerrilla campaign 
that challenged the democratic system. ${ }^{1}$ The maobadi aimed at a social revolution to install a 'new democracy' and to put an end to the monarchy. The civil war raged from 1996 to 2006 amidst violent clashes between security forces and the People's Liberation Army (PLA), with many civilian casualties, disappearances, war crimes and extra-judicial killings. In the meanwhile, at the royal court, crown prince Dipendra allegedly wiped out King Birendra and several members of his own family before committing suicide. These tragic events brought the king's brother, Gyanendra, to the throne. Amidst street protests and increased guerrilla mobilization, King Gyanendra suspended all parliamentary activities and curtailed civil liberties while at the same time giving more power to the army to fight the rebels. In 2006, a second jana andolan took place. In the dramatic weeks of April 2006, millions of people took to the streets to protest while the maobadi leadership launched a general strike. At the end of the month, Gyanendra again conceded powers to the parliament. The leaders of the main democratic parties (among them Nepali Congress and UML) signed a peace agreement with the maobadi to put an end to the civil war and to transform the country into a republic. Elections for a Constituent Assembly (CA) took place in 2008, transforming the Maoist underground into the major political force of the new parliament. Political oppositions and street protests often disrupted CA activities, and the new constitution saw the light only in 2015. One of the major obstacles was the issue of federalism, which stirred old and new rivalries and engulfed in the flames of riots the whole southern belt of the country, the so-called Terai, where the Madhesi launched uprisings after uprisings and armed groups tried to spark secessionist movements.

For the purposes of this article, I will focus on the dynamics affecting marginalized groups, undoubtedly among the main actors in all of the abovementioned phases and events. With the expression 'marginalized groups,' I refer here mainly to the janajati adivasi, which could be conveniently translated as "indigenous," "aboriginal" or "ethnic minorities." 2 As Gurung writes: "In recent years, the so-called disadvantaged or marginalised groups have emerged as a subject in Nepalese development discourse. Thus, the terms Janajati referring to ethnic people and Dalit referring to untouchable castes have come into currency" (Gurung 2005, 5).

While the Dalit ${ }^{3}$ communities are certainly marginalized, too, in the social framework of contemporary Nepal, I will not include them in the present discussion due to the fact that they are mostly included in discourses about the caste system (albeit, in most cases, as "untouchables"). In contrast, the janajati adivasi, despite technically not being included in the caste system either, were incorporated in the social framework of Nepal in two macro-groups, clearly differentiated from the menial castes. ${ }^{4}$

From a religious point of view, the janajati adivasi are not included in the fold of Hinduism. While some of the groups have certainly incorporated or absorbed elements of Sanskritic culture and especially of folk Hinduism to various degrees, they also consistently maintain indigenous traditions linked to the landscape and local deities belonging to original pantheons.

1 On the Maoist movement and the Nepalese civil war, see, for example, Thapa (2003), Hutt (2004), Gellner (2009), Lawoti and Pahari (2009).

2 In India, the term janajati adivasi is often translated as "tribal."

3 On the dalit communities, see Gurung (2005).

4 This differentiation already appears in the Muluki Ain, the 1854 Nepalese legal code, where the population of the kingdom was divided into five macro-groups: a) tagadhari o dvija (twice-born), b) namasinya matwali non-enslavable alcohol drinkers), c) masinya matwali (enslavable alcohol drinkers), d) pani na chalne choi chhito halnu naparne (impure castes), e) pani na chalne choi chhito halnu parne (dalit). The majority of the janajati adivasi communities is included in the groups b) and c). On the Muluki Ain and the Nepalese caste system, see also Höfer (2012). 
These religious systems very often clearly show a preponderance of shamanic elements, including dedicated part-time religious specialists acting as healers and mediators between their communities and the hosts of deities and spirits inhabiting the landscape. Despite local variations, a certain degree of homogeneity characterizes these systems in terms of beliefs and practices (Oppitz 2017). Some of the groups of the high mountains retain these elements even when formally adhering to one of the other Tibetan Buddhist traditions. ${ }^{5}$ Buddhism in itself has been revitalized by the most recent political turns in Nepal. Beside the very visible presence of the Tibetan diaspora, in fact, we find local Buddhist traditions pre-dating the coming of Tibetan refugees, as in the case of Newari Buddhism, or even the adoption of Theravada Buddhism by Tharu and Magar communities (Krauskopff 2009; Letizia 2014). ${ }^{6}$

The religious element is fundamental in the contemporary context. The revival of ethnic identities, and the revitalization of indigenous cultures, is a key element to understand current political developments. The same movements undermining the monarchy and its most feudal aspects challenged the state-promoted Hinduism, which granted, allegedly, the domination of high caste (bahun and chetri) groups. With the collapse of the monarchy, even Hinduism, considered one of its most efficacious pillars, has been put under severe scrutiny. As it seems, challenging Hinduism is to challenge the unjust social order which helped the establishment to maintain its privileges for centuries. It is in this framework that the revival of ethnic identities, while advocating equal opportunities and equal access to resources and services for all groups composing the civil society of Nepal, also strive for the recognition of the diverse cultures marginalized by the hegemonic Hindu high castes. A significant part of this so-called ethnic revival is devoted to marking distance from the hegemonic culture in every respect: from language to religion, from dress code to folk dances, every group is trying to resume, invent ${ }^{7}$ or valorize its specific traits in order to negotiate position, status and legitimacy with the other communities and with the state.

\section{The janajati adivasi}

It is hard to underestimate the rise of indigenous movements in Nepal, the place they occupy in contemporary politics and the pressure they are able to exert on the social and political sphere through their fronts, organizations and associations. Compared to India, where the Scheduled Tribes represent a consistent but limited percentage of the total population (around the 8\%), in Nepal they collectively constitute more or less one third of the population. As Toffin aptly summarizes, the impact they had on recent Nepalese political history can be measured in several areas, like the "ethnicisation of politics," "the massive success the Maoist met at the 2008 elections" (Toffin 2009, 27) and the addition, or sometimes imposition, of their agendas to the society at large.

The Nepal Janajati Mahasang, or Nepal Federation of Nationalities (NEFEN), ${ }^{8}$ was created at the beginning of the 1990s, at the end of the panchayat era. At the forefront of many campaigns against discrimination, for the rights of minorities and for the promotion of the disadvantaged groups, it became a major actor during the struggle for democracy and the

$5 \quad$ For example, among the Sherpa or the Hyolmo communities.

6 On Theravada Buddhism in Nepal, see also Kloppenborg (1977) and Leve (2002).

7 I obviously refer here to the notion of invention in its etymological sense, from the Latin invenio, meaning primarily "to find, to find out." I also refer obliquely to the notion of invented tradition made popular by Hobsbawm and Ranger (1983). 
republic due to its nature as an umbrella organization. Its success comes perhaps from capitalizing on the strategic unity among different ethnic organizations for the uplifting of the many groups subaltern to the parbatiya-dominated system. By 1996, the Federation included dozens of groups. In 2002, a list of fifty-nine ethnic minorities was officially recognized by the government (Toffin 2009, 30), which also produced an operative definition of the terms adivasi and janajati. According to the National Foundation for Upliftment of Aadibasi/Janjati Act, 2058 (2002), "Aadibasi/Janjati means a tribe or community as mentioned in the Schedule having its own mother language and traditional rites and customs, distinct cultural identity, distinct social structure and written or unwritten history." 9

From a state perspective, this means that criteria for recognition into this category amount to:

a) A language other than nepali

b) Particular customs and practices differentiating them from the Hindus

c) A distinct culture, again not Hindu

d) A social structure not based on the four varna (i.e. the four groups of the caste system)

e) A written or oral tradition

Taking into account these criteria, the state recognized fifty-nine groups. A year later, NEFEN changed its name into NEFIN (Nepal Federation of Indigenous Nationalities, or, in Nepali, Nepal Adivasi Janajati Mahasangh).

NEFIN official documents employ the same set of criteria used by the state to define indigeneity, including a different language, religion and culture from that of the rulers as well as a link with a specific territory before the formation of the modern state, founded by the Gorkha kings. Remarkably, two other criteria mention the condition of oppression, or being dominated, and having no or little representation in state organs. In this respect, the notion of indigeneity seems to go beyond the idea of a purely ethnic belonging, also combining it with an idea of marginality or subalternity, with scarce access to resources and infrastructures, and a condition of structural, social, economic, cultural and political subalternity. As in many other contexts, in Asia and beyond, "the salient characteristic of indigenous people, then, is that they are marginal to or dominated by the states that claim jurisdiction over them" (Maybury-Lewis 1997, 7).

NEFIN adopted a double criterion for classification: a geographical one, according to which the indigenous groups of Nepal are divided into four sub-groups according to the "traditional" environmental zone they inhabit-High Himalaya, Hills, Terai and Inner Terai; and a socioeconomic one, identifying five subgroups—endangered, highly marginalized, marginalized, disadvantaged and advanced. Significantly, only two indigenous groups of almost sixty figure as "advanced", the Newars and the Thakali, while all the others are variously positioned along a downward line (see table below).

\begin{tabular}{ll}
\hline Advanced groups (2) & Newar, Thakali \\
Disadvantaged groups & Tangbe, Teengaunle Thakali, Barahgaunle Thakali, Marphali \\
(14) & Thakali, Gurung, Magar, Rai, Limbu, Sherpa, Yakkha, \\
& Chhantyal, Jirel, Byansi, Hyolmo
\end{tabular}

9 See the National Foundation for Development of Indigenous Nationalities (NFDIN) webpage http://www. nfdin.gov.np/ (retrieved March 11, 2018). The NFDIN was established in the year 2002 by the then Prime Minister Sher Bahadur Deuba. 


\begin{tabular}{ll}
\hline Marginalized groups (19) & $\begin{array}{l}\text { Sunuwar, Tharu, Tamang, Bhujel, Kumal, Rajbanshi, } \\
\text { Gangaai, Dhimal, Bhote, Darai, Tajpuriya, Pahari, Topkegola, } \\
\text { Dolpo, Mugal, Larke, Lohpa, Dura, Walung }\end{array}$ \\
Highly marginalized & $\begin{array}{l}\text { Majhi, Siyar, Lhomi (Shinsaba), Thundam, Dhanuk, } \\
\text { Chepang, Santhal, Jhagad, Thami, Bote, Danuwar, Baramu }\end{array}$ \\
Endangered groups (9) & $\begin{array}{l}\text { Kusunda, Bankariya, Raute, Surel, Hayu, Raji, Kisan, Lepcha, } \\
\text { Meche, Kuswadiya }\end{array}$ \\
\hline
\end{tabular}

In 2007, Nepal became the first South Asian country to ratify the International Labour Organization (ILO) Convention on Indigenous and Tribal Peoples (ILO No.169) of 1989.

The Convention applies to (a) tribal peoples in independent countries whose social, cultural and economic conditions distinguish them from other sections of the national community, and whose status is regulated wholly or partially by their own customs or traditions or by special laws or regulations; (b) peoples in independent countries who are regarded as indigenous on account of their descent from the populations which inhabited the country, or a geographical region to which the country belongs, at the time of conquest or colonization or the establishment of present state boundaries and who, irrespective of their legal status, retain some or all of their own social, economic, cultural and political institutions. [...] Selfidentification as indigenous or tribal shall be regarded as a fundamental criterion for determining the groups to which the provisions of this Convention apply. ${ }^{10}$

The Convention was historically very important, for the first time setting an international agenda to safeguard indigenous people and their social, cultural, religious and spiritual values; to involve them in decision-making processes affecting their lives; and to give them voice and control over projects and plans involving their land, life, work, education and health condition at an international level. While its ratification is surely very important, linking the indigenous issues of Nepal within an international framework of recognition, its implementation in the Himalayan country is still weak.

On a global scale, indigeneity became an internally recognized socio-political item roughly at the same time of the Nepalese events of the 1990s. In fact, in 1993 the United Nations launched a Year of the Indigenous Peoples. A United Nations Permanent Forum on Indigenous Issues (UNPFII) was created on 28 July 2000 (resolution 2000/22) in order to deal with various indigenous issues across a multiplicity of areas, ranging from economy and social development to culture, education and health, human rights, access to credit, and environmental crisis. A first decade for the uplifting of marginalized indigenous people was declared by the UN between 1995 and 2005, followed by a second one up to 2015. Between April and May 2017, the sixteenth meeting of the UNPFII was held at the UN headquarters in New York, with a very specific theme: "Tenth Anniversary of the United Nations Declaration on the Rights of Indigenous Peoples: measures taken to implement the Declaration."

As often stated in official documents, there is still a considerable amount of debate surrounding the notion of 'indigenous.' For example, in the UN Resource Kit of Indigenous People Issues, we find the following paragraph:

10 Cited from http://www.ilo.org/dyn/normlex/en/f?p=NORMLEXPUB:12100:0::NO::P12100_ILO_CODE: C169 (retrieved March 11, 2018). 
The international community has not adopted a common definition of indigenous peoples and the prevailing view today is that no formal universal definition is necessary for the recognition and protection of their rights. However, there have been attempts to outline the characteristic of indigenous peoples (Resource Kit of Indigenous People Issues, UN, New York 2008, 7-8).

Nonetheless, a working definition of indigenous is provided and used drawing on a previous report entitled The Study on the Problem of Discrimination against Indigenous Populations (also known as the "Martínez Cobo Study"), where it was stated that:

Indigenous communities, peoples and nations are those which, having a historical continuity with pre-invasion and pre-colonial societies that developed on their territories, consider themselves distinct from other sectors of the societies now prevailing in those territories, or parts of them. They form at present non-dominant sectors of society and are determined to preserve, develop and transmit to future generations their ancestral territories, and their ethnic identity, as the basis of their continued existence as peoples, in accordance with their own cultural patterns, social institutions and legal systems (Martínez Cobo 1986).

In Nepal, the notion of 'indigenous' was elaborated from the word adivasi, a term popular since the 1920s on the Indian sub-continent ${ }^{11}$ and used to refer to those communities defined as tribal by the state apparatuses before and after independence from the British Empire. ${ }^{12}$ While in India the term tribe has a legal recognition, it was never officially used in Nepal, where it is also thought of as a derogative term (Toffin 2009, 40). The term adivasi, through its literal meaning of "original inhabitants," instead conveys those ideas of links between people, time and place so dearly cherished by ethnic activists. The ancestral bond with a territory is in fact conceived and reified as the basis for the development of exclusive ethnic communities. As Battachan and Pyakuryal argue, we can define ethnicity, in the Nepalese contexts, as a variable degree of identification with a set of symbolic traits, including religion, language, customs and beliefs, together with a sense of a shared history and a common origin (Bhattachan and Pyakuryal 1996, 17).

It is certainly true that in the course of its historical expansion, the Nepalese state encroached upon territories once held by non-urban societies exerting variable degrees of control over their lands. ${ }^{13}$ Following military conquest, a wave of Hindu settlers spread over newly acquired lands (Caplan 1970; Toffin 2009, 28). Incorporation proceeded during the twentieth century, together with the "enduring process of Hinduisation" (Toffin 2009, 28), combining efforts to modernize the country and society while at the same time molding a national shared identity under the overarching framework of the Hindu kingdom and its apparatuses. To a certain extent, the rise of the indigenous ethnic movements may be seen as a response to their marginalization and exclusion until the 1990s and 2000s. The movements for democracy in the 1990s, the growth of the Maoist movement-which shared, as we have seen, some parts of its agenda with ethnic minorities-and the merging of these two trends in the month of November 2005, when the seven-party-alliance (SPA) joined forces with the Maoists to deliver the final push to Gyanendra's autocratic experiment-saw unprecedented, mass-scale participation of the ethnic communities to national political life.

11 On the history of the adivasi movement in India, see Dasgupta and Basu (2012).

12 For a discussion on the application of the term 'tribe' in Nepal, see also Caplan (1990).

13 For a historical overview, see Whelpton (2005). 
Yet the janajati movement, despite its apparently egalitarian, pro-democracy, pro-inclusion aims, possesses a darker, perhaps menacing, side. Ethnic activists, in fact, propose dangerously essentialist conceptions which reify communities as "self-contained and unchanging entities, closely associated with a particular tract of the land" (Toffin 2009, 30). Their views are primordialist (Gellner 2008, 7), uncritically postulating the existence of static ethnicities since time immemorial, while in fact they are to be understood as responses to contemporary trends and pressures (Gellner 2008, 11). The solidification of ethnic identities is potentially a multiplier of conflicts between diverse social units and neighboring communities. The activists' emic view privileges imagined purity and minimizes contact and exchanges, forgetting that individual and collective selves are always co-produced through exchange and negotiations with others and not produced in the perceived and proposed condition of pristine, original isolation, as amply demonstrated by Barth (1969). These sets of postulates are to be considered ideologically functional for a project and actively enforced or built (Kievelitz 1996, 3). Ethnicity is not inherently derived from the use of a particular language, the sharing of songs and dances, or common religious rituals and beliefs, but from an active process, or processes, conferring a particular meaning to all these elements. Toffin has formulated a critique to the autochthonous paradigm, arguing that:

such views clearly contradict democratic ideals, which presume escaping from all sorts of ascribed links (family, caste, religion) inherited from the parents, and the freedom of all citizens to settle wherever they like throughout the national territory, except in restricted areas. In the indigenous discourse, primordial bonds are favoured to the detriment of civic ties. Political society is viewed as made up of groups not individuals (Toffin 2009, 34).

This is particularly true with reference to the issue of ethnic federalism, which disrupted and delayed the works of the Constituent Assembly (CA) repeatedly between 2008 and 2015. Originally also envisioned by the Maoist movement, which proposed the creation of ethnic autonomous regions, the issue of ethnic federalism pursued after the end of the civil war became one of the major problems for the country, fostering the rise of communalism, exacerbating relations between neighboring communities and setting the ground for further polarization and the possible escalation of violent confrontations. The risk of balkanization (Singh and Kukreja 2014,172 ) is concrete, given the volatile political environment and the confrontational stance of many groups, including armed underground factions. Nepalese social pluralism was historically subsumed within the fold of the Hindu state, whose collapse and forced dismissal at the end of the civil war determined an unbalance in power assets and power relations between different social units. The quest for a new balance, pursued through the federalist project, could turn towards threatening forms of ethno-nationalism: already during the civil war, several Maoist guerrilla fronts were conceived as ethnoregional autonomous political units, as in the cases of the Madeshi Mukti Morcha, Magarat Mukti Morcha, Newa Rashtriya Mukti Morcha, Tamang Mukti Morcha, Tamuwan Mukti Morcha, and Tharuwan Mukti Morcha (Lawoti and Pahari 2009). While undoubtedly grounded in a class war perspective, these fronts also courted and nurtured ethnic sentiments which, after the civil war, in some cases fostered chauvinistic feelings and demands for autonomy and secessionism. 


\section{Towards a Secular Nepal?}

Beside the issue of federalism, secularism became a very popular and widely debated topic among Nepalese intellectuals, politicians and lawyers. In a carefully researched paper, Letizia (2016) gives us a detailed overview of such a debate, highlighting its key features and offering insights into different, often diverging, ideas and interpretations. Inasmuch as the struggle to topple Gyanendra was also a movement advocating the end of the Hindu monarchy, secularism, aiming at the recognition of religious pluralism in Nepal, became common currency among the majority of political, ethnic and religious activists. A secular Nepal was also envisioned by the Maoist leadership, secularism being intrinsic to any project of 'new democracy. ${ }^{14}$ Nepal was proclaimed a secular state on 18 May 2006 (Letizia 2016, 35), shortly after the end of the second jana andolan, which forced the king to reinstate the parliament, paving the way to the peace-agreement with the Maoists, and to the establishment of the Republic. Secularism was formally introduced in article 4 of the Interim Constitution of 2007, and in May 2008, the Constituent Assembly, dominated by the Maoists (CPN-M), finally declared the country a secular republic, or, in Nepali, a dharma nirapeksa rajya, a "state autonomous from religion" (Letizia 2016, 36). This was the direct outcome of years of parallel campaigns for democracy, for the rights of indigenous minorities, for religious freedom, for the republic, for socialism and against the monarchy. Different groups with very diverse agendas identified the Hindu ideology, in one way or another, as one of the driving forces of the monarchic establishment, and a pillar of its structures of power. More specifically, several groups and movements were campaigning, for different reasons, against a state perceived as Hindu. In contemporary political jargon in Nepal, they were campaigning for 'secularism', by which they primarily meant 'non-Hindu'.

Campaigns for secularism appeared in the public sphere in the 1990s, due to a movement launched by the Theravada monks with the support of activists belonging to the janajati communities (Letizia 2016, 42). Their aim was not "to banish religion from the public life, but to obtain equal recognition" (Letizia 2016, 42) for the followers of religious traditions besides Hinduism. As such, it was a movement overtly challenging the hegemonic position of Hinduism. Since its inception, therefore, the issue of secularism saw an entanglement between religious expressions, political mobilization and specific links with segments of the population of Nepal, which were marginal to the Hindu-dominated state machine. Since Hinduism provided the state with its main ideology, thus giving primacy to some groups while at the same time assigning the others subaltern positions, secularism became the flag under which to fight for "minority inclusion in all these spheres and for recognition of the multi-ethnic and multi-religious composition of the country" (Letizia 2016, 43). In the case of the Hyolmo, Sherpa and Tamang, for example, the public display of Buddhist features became a pivotal element of ethnic representation (Berg 2003; Holmberg 2016; Torri 2017). As for other groups, religious identity constitutes a key element of differentiation and specificity. As such, it gained a prominent position in all public and collective events, ranging from political demonstrations to proper religious rituals. The two dimensions appear strictly intertwined, or, as Shneiderman aptly remarks, to a certain extent we can say that ethnicity itself is a ritual (Shneiderman 2015, 58). As a matter of fact, the boundaries between political demonstrations,

14 The concept of 'new democracy' is a classic tenet of Maoist political strategy, envisioning a coalition of classes fighting together to overthrow the feudal order as a necessary step to advance towards socialism. The concept was theorized by Mao in his famous essay, titled On New Democracy (1940), and adopted by various Maoist groups engaging in revolutionary activities from the 1960s onwards. 
religious rituals and displays of cultural features (songs, dances), appear extremely blurred, and each public event embraces all the aforementioned spheres. ${ }^{15}$ I clearly remember my surprise when, contrary to my expectations, I saw my first demonstration for the implementation of secularism. Lines after lines of demonstrators, tightly organized and belonging to several groups, were marching towards the parliament. Each segment was apparently led by religious figures, including shamans drumming in full regalia, to highlight their specificities vis-à-vis the state and to claim equal recognition for the most diverse religious expressions and feelings. At the same time, the demonstration was not organized according to an overarching religious criterion, i.e. Muslims, Buddhists, etc., but by the community.

It is almost impossible to underestimate the role of religion in the process of asserting one's ethnic identity. In this regard, we could almost equate the building of the Hyolmo Gompa ${ }^{16}$ in Tinchuli (Kathmandu) with the growing awareness of Hyolmo identity itself (Torri 2017). After all, the Gompa provided a safe space and a cornerstone from which to articulate, express and display - that is, shape internally and make visible externally-their specificity. The rise of worship places related to minorities' different religious traditions constitutes a salient element of the movement for secularism, providing each group with a proper environment through which to project themselves onto the larger framework of the Nepalese social landscape. The construction of new worship places epitomizes the spread of religious identities or rather, their surfacing to public life and quest for recognition. The same applies to religious festivals, which became a "primary productive activity directly related to formations of identity and political demands for recognition in contemporary Nepal" (Holmberg 2016, 302). The growing number of religious celebrations is part of a campaign for equal treatment by the state, up to the incorporation of non-Hindu festivals in the schedule of national holidays. As it seems, the de-Hinduization of the Nepali state apparatuses requires a proper political environment (the parliament, the constitution), a dedicated space (new sacred spaces, temples, shrines etc.), the 'revival' of folk/traditional practices (songs, dances), and even dedicated days (holidays and religious festivals) in which to conjure all of the above in the making and displaying of ethnic identities. A quick look at the Nepalese calendar will suffice to demonstrate this trend: to name only a few, the list of public holidays in Nepal, beside the Hindu festivities (Shivaratri, Krishna Janmasthami, Dashain, etc.), now also include the Buddha Jayanti and the Lhosar, the birthday of Muhammad and the end of the Ramadan, Christmas Day, together with Democracy Day, Constitution Day and Martyrs' Day.

A common theme seems to resurface in all these expressions of indigenous religions' revivals and among new religious movements at the fringe of orthodox Hinduism. This fil rouge is the invocation of a deep connection between the turbulent present and an imagined distant past. In the idea of tradition itself, the past is often invoked as an infinite, and intangible, source of legitimacy. Thus every revival transforms an idealized past into a desideratum and uses such a model as a source of originality and authority. The dialectic of the present and the past also entails an opposition between change, corruption and the risk of loss (usually associated with the present) and stability, authenticity and purity (usually associated with the past). Yet every revival could be seen as an innovative process to adapt to new contexts, all the while proclaiming adherence to the old ways in the days of yore. Nepal's intermediate past, inherently corruptive, seems to correspond to its recent history, from the eighteenth century, when the country was unified, up to the last king of the Shah dynasty. In the minorities' view,

15 See, for example, Wettstein (2016) on similar processes among the Nagas in Northeast India. 
these two centuries correspond to the effort to create a national identity by superimposing the Nepali language and Hindu religion, just like the minor reigns and chiefdoms of the Himalayan hills were annihilated in the imperialist campaigns of the king of Gorkha. ${ }^{17}$

The new Nepal, striving towards secularism, is more religious than ever. But what kind of secularism is actually being debated in the country? The 2015 Constitution refers to 'secular' as dharma nirapeksa, 'neutral to religion.' The closer term of comparison is taken from the Indian 1976 Constitution, where the discussion on secularism, ${ }^{18}$ or, conversely, on the role of religion in its relation to the state, was articulated mainly along two lines, as argued by Arvind Sharma:

The first term is dharma-nirapeksa. This reflects Nehru's understanding of it, for whom religion belonged to the past and the future belonged to science alone. So the state should have nothing to do with religion because it was something backward, the opium of the masses. This concept of secularism implies a negative assessment of religion. The other term used to represent the word secularism in Indian languages is sarva-dharma-sama-bha-va. That is to say, looking upon all religions as the same, not in the sense that they are all the same and there is no difference among them, but in the sense that all are equally entitled to our respect and consideration. This reflects Gandhi's understanding of the term, who identified religion with morality and respected all religions. For Gandhi, unlike Nehru, religion was not something to be avoided but to be inculcated, but without giving preference to any one religion (Sharma 2013).

The role of religion and its relation with the state was a defining, even pivotal, issue since the rise of the Indian independence movement through the formation of organized groups in the late 1880s. Due to the predominance of Hindu members in the Indian National Congress, and especially after the Partition of Bengal in 1905, Muslim activists created the All-India Muslim League in 1906 to protect the interests of the Islamic communities. This rift in the independence movement led to the creation of India and Pakistan in 1947. Discussions on the role of religion within the state characterized the political debate long before the actual realization of Independence. During the 1930s, Gandhi articulated his views as sarva dharma sambhava, indicating that all religious expressions should be equal before the state. This concept, imbued with spiritual undertones shared also by Ramakrishna and Vivekananda, is based on the idea that all religious paths lead towards the same goal, although they may differ in practices and beliefs. Ambedkar criticized this position, arguing that some religious expressions were keeping people in a subaltern position, as in the case of Dalit people in the fold of Hinduism. The dharma nirapeksha view, promoted by Nehru, is grounded instead in the values of modernity and rationalism, aiming at the separation of religion and state, and ideally relegating religious ideas to the private sphere while science replaces it in the public one. In the Indian Constitution, fundamental religious rights are granted in articles 25, 26, 27, 28, 29 and 30, which establish religious freedom for all citizens and the right to form religious institutions, exclude religious education from the state-founded education system and protect the "interests of minorities" and especially their rights to preserve "a distinct language,

17 The term 'Nepal' was used originally to indicate the Kathmandu valley only, while the rest of the country was parceled between small kingdoms and indigenous independent chiefdoms, with large traits free of political authority beyond the village level. After conquering Kathmandu (1768), Prithvi Narayan Shah of Gorkha made it the capital of the new reign.

Secularism was amply debated in India since before the Independence of 1947. 
script or culture of [their] own" (Constitution of India, Art. 29), which is particularly relevant to the adivasi situation. In drafting the new constitution, the members of the Nepalese CA (Constituent Assembly) ${ }^{19}$ were striving to produce an advanced democratic system, firmly centered on secular values, as reflected already by articles of the Interim Constitution.

The 2007 Nepalese interim Constitution, in fact, defined the state as secular, a feature later also confirmed in the 2015 Constitution: "Art 4. State of Nepal: (1) Nepal is an independent, indivisible, sovereign, secular, inclusive, democratic, socialism oriented, federal democratic republican state." ${ }^{20}$ An explicative note follows: "For the purposes of this Article, 'secular' means religious, cultural freedoms, including protection of religion, culture handed down from the time immemorial." 21

While this passage seems to grant religious freedom and equality to all the religious expressions of marginalized groups, according to Letizia, it also "evoke[s] the notion of sanatan dharma" (Letizia 2016, 69), the eternal religion of the Hindus. In the end, while the initial ideas of secularism were mainly and openly anti-Hindu, the final version of the process seems more reconciling. Undoubtedly, even the staunch views of the Maoist delegates were pragmatically mitigated by taking into account the ideas of their Hindu fellow members of the parliament. The ban on proselytism and conversion (Art. 26.3) seems a relic from the monarchy days, although it was explained as a measure to contrast the aggressive conversion campaigns launched by Evangelical Christians after the fall of the monarchy. Conversion campaigns increased especially after the 2015 earthquake. ${ }^{22}$

In the context of the Nepalese process towards a secular state and a secular society, the religious field is one of the main arenas where different groups meet and forge alliances or compete with each other. Even more interesting is the process of intensification affecting nonHindu religious expressions. As a matter of fact, in every public event where ethnicity and cultures are displayed, the religious element vehemently appears.

\section{Three Case Studies}

In order to exemplify the aforementioned trends affecting Nepalese society, I will briefly take into account three different case studies ${ }^{23}$ dealing with religious dynamics among the janajati adivasi. The first one refers to the role of Buddhism among the Hyolmo people of Helambu valley. ${ }^{24}$ Buddhism, in its Tibetan (nyingmapa jangter) version, constitutes the key element of

19 Actually, two distinct Constituent Assemblies worked on the Constitution of Nepal: the first one was in charge from 28 May 2008 to 28 May 2012, with the Maoist Party (CPN-M) as the major political force; a second CA was elected in November 2013, with the Nepali Congress as the main force. The new Constitution was promulgated on 20 September 2015, in the aftermath of the catastrophic effects of the earthquake. The promulgation sparked unrest in the southern regions, and led to a blockade of the border with India.

20 http://www.constitutionnet.org/vl/item/constitution-nepal-2015-official-english-translation-ministrylaw-justice-and-parliamentary (retrieved on February 25, 2018).

21 http://www.constitutionnet.org/vl/item/constitution-nepal-2015-official-english-translation-ministrylaw-justice-and-parliamentary (retrieved July 7, 2019).

22 See for example, http://www.christianitytoday.com/news/2017/october/nepal-criminalizes-conversionchristianity-evangelism-hindu.html (retrieved February 25, 2018).

23 Sources from the three cases studies include data from my own fieldwork among the Hyolmo between 2006 and 2015, with parallel research among other adivasi communities (i.e. Tamang and Sherpa) in relation to various forms of shamanism and possession-related phenomena (i.e. female possession and Tibetan oracles). For the sake of comparison, I employed data from the research of Martin Gaenszle on Rai shamanism and Pustak Ghimire on female possession in eastern Nepal (see bibliography for full references).

24 The Hyolmo people, previously known as Helambu Sherpa (Bista 1967), Lama people of Helambu (Clarke 1980a, 1980b, 1983, 1985) and Yolmo (Desjarlais 1992, 2003), are one of the janajati adivasi traditionally 
the Hyolmo claim to specificity. Quite paradoxically, we could say that to be a real Nepalese minority (janajati adivasi), the Hyolmo people have become more and more Tibetanised over the years. I use the word Tibetanised to describe a process of re-definition of identity, which brings them closer to Tibetan Buddhist orthodoxy, highlighting those traits and features of their indigenous culture that are markedly "Tibetan." Recent migration of the community from Helambu villages to the outskirts of Kathmandu Valley had a deep impact on the pace of the process of self-identification, which has significantly increased.

The Hyolmo Buddhist indigenous tradition-previously grounded in non-celibate, nonmonastic lama lineages, where the religious role was, and in certain cases still is, transmitted from father to son-has transformed in the move from the villages to the city. The more evident changes revolve around the construction of the Hyolmo Gompa, which is at the same time a religious building and the headquarters of Hyolmo Samaj Sewa Sangh. We could say that it constitutes the cornerstone of Hyolmo identity in the Kathmandu Valley.

Hyolmo Buddhism was previously focused on a network of sacred places associated with specific locations of the Helambu valley. Here, following the model of a mandala, sacred spaces included spirited mountains, meditation caves and holy shrines. According to Hyolmo written and oral traditions, Helambu valley is in fact Yolmo beyul, 'the secret place protected by snowy peaks,' also known as Pema tshal, 'the lotus grove.' According to the legend, it was blessed by Padmasambhava and then sealed to be opened in times of danger for the dharma. During the fifteenth century, the reincarnated lama and treasure revealer Shakya Zangpo found a text with instructions to reach the Kathmandu Valley and find an abandoned stupa. After finding and renovating the Bodhnath Stupa, known in Tibetan as Jarung Kashor Chorten, on his way back to Tibet he received further visions with instructions to open the hidden valley of Yolmo. From the establishment of the first shrine at Churi Ghyang, the Hyolmo trace, retrospectively, the beginning of their history as a community. Since the 1980s, the Hyolmo have been present in the Kathmandu Valley, in the areas close to the Bodhnath stupa. Initially, they were mainly involved in the carpet industry, but with the passing of time, they diversified their economic activities in the urban context, becoming relatively successful shopkeepers, entrepreneurs and tourist operators. A significant number of Hyolmo people work abroad, mainly in South Korea and the Middle East, but they are present also in Europe and in the USA.

In the present day, I think it would be possible to claim that, despite the original importance of the Helambu villages and associated shrines, the Hyolmo Gompa in the Kathmandu Valley acquired a primary position in the process of identity building. There are multiple reasons for this. Firstly, the urban Hyolmo population has grown over time, and dramatically increased during the civil war and even more so after the earthquake. While Helambu remains the original background of reference, the community seems to have successfully operated a substantial shift from the agricultural life of just twenty years ago. Hyolmo Gompa is the material support for this relocation, allowing the community to refocus around a new sacred center, just like village life used to revolve around local shrines. At the same time, in the new urban context, the Hyolmo people were confronted with a greater necessity to define themselves amidst the other groups of Nepalese citizens, both in terms of group identity and in terms of religion. Especially regarding religion, they were confronted with other Nepalese Buddhist traditions and with the overarching influence of Tibetan religious establishments, whose presence has almost

inhabiting the Sindhupalchok district. In particular, they are associated with Helambu Valley, known as Yolmo in Tibetan sources. Nowadays they also have a stable representation in the area of Bodhnath, in the Kathmandu Valley, and in diasporic communities in India, the Middle East, the United Kingdom, the Republic of Korea, the United States and other places. 
overshadowed local expressions. Hyolmo village lama-lineage holders have been drawn closer to orthodoxy: rituals have generally become more elaborate and more grounded in textual sources. The overall level of literacy of the community in written Tibetan has increased, leading to more participation in collective rituals involving the reading of the namthar literature. Major ritual happenings at the Gompa also involve trained religious dancers and musicians in great numbers, and often involve the presence of Tibetan high lamas from allied traditions (Nyingma and Kagyu). The Gompa also serves as a place for rehearsing traditional folk songs and dances, the intangible heritage now on display at almost every public event. In a similar way, material heritage (i.e. clothes, costumes, hairstyle, jewelry, utensils, etc.) is becoming more and more standardized for consumption during public events.

The Hyolmo indigenous religious system, despite being markedly oriented towards Buddhism, includes a residual presence: a shamanic complex, in a peripheral position compared to Buddhism, and in a relationship of competition and complementarity with it. Among the Hyolmo people, in fact, we find a composite economy of the sacred, where several areas of intervention (mainly healing, divination and exorcism) fall under the domain of a shamanic religious specialist known as pombo or bombo. These words, obviously related to the Tibetan term bön, are employed by the Hyolmo people to indicate a shamanic religious specialist whose worldviews, beliefs and practices are very similar to the pan-Nepalese figure of the jhankri. The word jhankri usually indicates a part-time religious specialist possessing the power to engage the non-human world on behalf of his or her sponsors and patients in order to negotiate health, luck, long-life and well-being with the host super-human entities populating the cosmos. He does so during all-night rituals, where a modified state of consciousness (expressed in the Nepalese language by the verb kamnu, "to tremble/shiver violently") is attained through the constant beating of the drum. The power to shamanize is usually obtained at a young age, after an illness which is considered a sign sent by ancestors and which is followed by an apprenticeship with an acknowledged shaman. Composite religious systems are very common among the Himalayan indigenous groups, as extensively reported by many researchers (Berreman 1963; Holmberg 1989; Mumford 1990; Balikci 2008; Torri 2014).

Co-presence of religious specialists seems to have been the norm also among the Tamang (see, for example, Steinmann 1987; Mastromattei 1988; Holmberg 1989; Höfer 1994; Campbell 2013), the Sherpa (Oppitz 1974; Ortner 1978, 1989) and the Gurung (Pignède 1966; Mumford 1990). But what we are witnessing now is a reformulation of the composite religious sphere in order to match and keep pace with the already mentioned ethnic revival. In this regard, the situation among the Rai of Eastern Nepal (Gaenszle 2000, 2002) is also very interesting, where we find a reformulation of the indigenous religion, with elements drawn from the shamanic-animistic complex and Hindu bhakti (devotional) currents. The Kiranti ${ }^{25}$ religion is grounded in an "inherited knowledge concerning the ancestors" (Gaenszle 2000, 224), called mundhum, ${ }^{26}$ and was, until very recently, transmitted mainly orally. The mythology of the Kiranti groups includes cosmic creation, origin and migration stories. As such, it constitutes an indissoluble element of ritual practice and stresses the link between people and territory. In the context of ethnic revival, the Kiranti religion is not only an element of identity but also a direct claim towards a portion of the land, which, as we have seen before, is part and parcel of the debate about federalism in Nepal. As remembered by Martin Gaenszle,

25 The term Kiranti defines a group of languages spoken in eastern Nepal. In contemporary Nepal, the so-called Kirat people include the Limbu, Rai, Yakkha and Sunuwar indigenous groups.

26 Different groups have slightly different terms to define this knowledge. Besides the already mentioned mumdhum, we find also muddum, mundum, mukdum and other variations (see Gaenszle 2016, 328). 
"the mythic appropriations of the land by the ancestors are periodically commemorated in order to express this claim" (Gaenszle 2016, 331). Beside mythic references to an ancestral land, the Kirat people still have historical memory of the communal land system known as kipat (Caplan 1970; Subba 1999, 51-55), dismantled by the monarchy. Ethnic associations and organizations are very active in recovering this idea of a pristine, ancestral land as an autonomous political region. Ideas of a pan-Kirat identity are also enshrined in the Kirat temple at Hattiban in Kathmandu Valley. Here, around a central pillar, the four typical altars of the Limbu, Rai, Yakkha and Sunuwar are oriented according to the different cardinal points, and members of the different, yet unified, indigenous groups can worship side by side under the overarching framework of pan-Kirantism (see Gaenszle 2016, 345-46).

Shamans, besides acting as ecstatic folk-healers, are also actively involved in the political organization of the community. Yet as mentioned already, new religions are emerging among the Rai, partially merging the indigenous traditions with elements taken from Hindu ascetic or devotional (Bhakti) traditions. Among these, the cult of Guru Om Nanda, also known as Supreme Master Godangel, is spreading fast among younger Rai generations. It proposes a mix of "Santism, Buddhism and New Age religion, including a portion of ethnic traditions" (Gaenszle 2016, 335). New, syncretic religious movements of this kind are mushrooming in Nepal. ${ }^{27}$ Their growth is historically usually associated with times of crisis and social change, on the one hand, and with the rise of an educated middle class exposed to globalization and seeking "sanitized" or reformed religious practices, detached from all aspects rubricated as backward or superstitious, on the other. As elsewhere, these movements have a focus on health and happiness, meditation, Ayurveda, yoga, etc., instead, which have made Indian gurus famous around the world time and time again.

The last case study will refer to the phenomenon of female possession among different groups, a phenomenon that increased during the civil war years and is transculturally spread among indigenous and Hindu low caste groups. Female possession in the Indian sub-continent is usually linked to the cult of Devi, the Goddess, in one of her manifold guises. The kind of possession ${ }^{28}$ we are discussing here is not the negative, or demonic, one, but the one endowing the possessed with spiritual gifts or powers, and allowing her to act or speak on behalf of a superior entity on an almost regular basis. The pattern is very common: after a personal crisis, a woman discovers that a female deity ${ }^{29}$ has chosen her. The goddess, generally known by the appellative of Bhagavati, grants her devotee powers of clairvoyance, healing and blessing. Interestingly, the possessed women act as religious reformers and connect themselves to the practices of the higher castes (refraining from meat, fasting, meditating) usually associated with orthodox Brahmin males.

I remember visiting one of these Guru Ma a few years ago, on the outskirts of Kathmandu Valley. ${ }^{30}$ She was very popular in the neighborhood and in order to get an audience with her, one had to queue in front of her house beginning in the early hours of the morning. In the lines, there were many people seeking her advice, blessing or a miracle. In her house, there was a shrine for her activities, where she could receive her petitioners one by one. Inside, she used to be seated on a high chair, like a golden throne constituted by seven intertwined cobras whose heads protruded above her shoulders. Completely clad in red, she sat almost

$27 \quad$ On this topics, see also Toffin (2016).

28 For a general discussion on possession, see Lewis (1971); Bourguignon (1976); Schmidt and Huskinson (2010). For a discussion on possession in South Asia, see Smith (2012) and Sax and Basu (2015).

29 On the goddess cult in South Asia, see Hawley and Wulff (1996).

30 Bajranagar (Nepal), April 2008. 
motionless, listening to the people bowing in front of her, and replied calmly with her eyes only partially open while giving them advice, muttering mantras and blessing them with holy waters sprinkled with the help of a peacock feather. Her services were available on a daily basis until noon. After that time, she 'became' a normal young woman in her early twenties again. For the purposes of my research, and to conduct an academic interview, I had to wait for the end of the 'state of grace' into which she plunged daily from midnight until noon. Her story was typical of many mothers, as they are called, with a reference to Devi as the Mother Goddess. Her personal crisis began with being scolded while at primary school. After one teacher's harsh reproaches, she fell ill for a long time and started experiencing visions of the Goddess. During these visions, she was instructed to follow special dietary customs, a strict path of purification, meditation and prayers. Slowly, she emerged as a holy person with a discrete number of followers, but in a few years she was so popular that her religious duties became her main activities, and her house changed into a local religious focus for the whole suburb. Visiting her from year to year, it was possible to see the changes in her attire, paraphernalia and the setting, testifying an increase in her personal charisma, paired with an augmented authority and the development of a stricter protocol to access her services and address her. A similar pattern of changes affected her house, which underwent renovation from a small and humble rural traditional home to include a detached and very elaborated shrine.

In a recent work, the Nepalese anthropologist Pustak Ghimire links the diffusion of the phenomenon ${ }^{31}$ to societal crisis and the increase of violence during the civil war, but also to the parallel, or ensuing, growth of self-confidence experienced by many women in those years (Ghimire 2016, 178). Similarly, David N. Gellner hinted at the political dimension of mediumship as rebellion and contestation of one's own condition (Gellner 1994, 43), especially in the context of the 1990s wave of democratization. Common among the Hindu and the Newari people, a religious phenomenon of female possession spread among other marginalized groups as well, like the Dalit and the janajati Adivasi. Quite interestingly, the spread of bhagavati among the marginalized and oppressed groups contest the male Brahmanical orthodoxy while at the same time mimicking it. Those traditionally excluded from it adopted high caste behavior as a challenge to the establishment but also as a way to advance, ameliorate and transform social relations.

\section{Conclusions}

In the context of the contemporary situation of Nepal, where the social and political landscape appears fragmented and characterized by extreme volatility, religion, idiom and territory are constantly evoked to support claims of specificity in order to negotiate groups' status, recognition and legitimacy. The two intertwined dimensions of secularism and federalism probably constitute the main areas of debate, and the campaigns to support, or to contrast, these are intrinsically tied to the country's internal diversity and richness of religions, languages and cultures. In the present paper, having assessed the role and importance of marginalized groups in the political life of the last thirty years, I focused on some aspects of religious dynamics involving those marginal groups usually referred to as indigenous, or, in the Nepalese language, janajati adivasi. While the three aforementioned cases are just examples and surely not exhaustive of the whole range of dynamics, they nonetheless serve well to highlight a limited 
set of patterns unfolding among at least some of the marginalized groups of Nepal. The role of Buddhism among the Hyolmo people, the Kiranti religion among the indigenous groups of Eastern Nepal and the spread of female possession among several groups, in fact, call into question the notion of tradition and its perceived stability in the context of change. In all the cases, tradition is invoked through a vertical connection with the past, in some cases, and with the land or with deities, in others, as a direct source of authority and legitimacy.

The ethnic revival of indigenous nationalities is grounded on a claim of a specific identity, based on the possession of a distinct language and culture, a particular religion different from Hinduism, and an historical-mythical relation with a portion of territory of the contemporary Nepalese state. The oppositional stance of these groups against Hinduism or a perceived stateHinduism derives from a historical deconstruction of the dynamics leading to state formation, starting from the unification of the country at the hands of the King of Gorkha Prithvi Narayan Shah through his aggressive campaigns of expansion during the second half of the eighteenth century. The modern state of Nepal, in the form of a Hindu monarchy, sustained inclusion of the indigenous groups in the fold of a society ideally oriented along criteria of the Hindu high castes, of which the king was the highest personification and guarantee. To a certain extent, the Nepalese monarchy could be understood as a theocracy, since the king was invested with the divine power of the god Vishnu, and Nepal remained, and still is, especially for right-wing Hindu organizations, asal Hindustan (the true land of the Hindus). In this respect, the revival of marginalized groups can be explained also a movement to disentangle themselves from the monarchy's process of creating a national identity based on Hindu culture as a medium for inclusion and on the primacy of the Nepali language as a tool of modernization. The long impasse characterizing the writing of the constitution (2008-2015) can be explained also by taking into account all the efforts to shatter old privileges and resistance to those very same efforts. In addition, significant competition among different political groups, ethnicities and even international pressure added obstacles to the process of transformation from a Hindu monarchy into a secular and federal republic.

Despite intrinsic diversity, several trends can be identified from a religious perspective. The first is certainly a move towards an internal homogenization and standardization of practices. The formation of ethnic associations was a key feature of political life of contemporary Nepal, and those associations and organizations constantly worked towards refining cultural elements in order to produce an essential set of features enabling internal and external legibility. I use the concept of 'legibility' here following James Scott's notion of a process to "make society legible" (Scott 1998, 2), creating a visible and coherent image. While for Scott this is primarily a state activity, I would argue that ethnic associations behave in a similar way to produce legible images of their groups, to be recognized by the state as legitimate units and at the same time to be diffused among the group members themselves in order to be interiorized and embodied. Legibility, thus, applies to the two intertwined internal and external dimensions: culture becomes standardized for synchronic internal and external consumption. This process is exemplified by the blossoming and multiplication of ethnic festivals. In recent years, ethnic festivals have become major events to display and highlight identities, but also events where group members increasingly become spectators of their own cultures, as argued, for example, by David Holmberg in the case of the Tamang Lhochhar (new year) Festival (Holmberg 2016, 317). The process of homogenization of diverse, local traditions into a canon of sorts serves the purpose of producing a coherent image of the group's culture, heritage and folklore to be traded with other groups for mutual recognition of specificity, a specificity based on 
a presumed notion of a pristine originality prior to the incorporation into the Hindu state. In this regard, the different groups seem to follow a protocol: through a selective process, community activists engage in the recreation, or invention, of presumed authentic cultural traits, culminating in a more or less strict codification of features. An example of this process could be the standardization of shamanic practices: among the Hyolmo, to name just one case, the creation of a Nepal Hyolmo Bön Preservation Society produces intense exchange between previously highly individualistic religious specialists. The obvious result is a modification, at the ritual level, of those differences perceived to be divergent from the "original" rite's procedure. For example, following a fierce debate, blood-sacrifices, i.e. the killing of an animal victim, is currently under intense scrutiny and almost banned from actual practice. While this is certainly due to the growing influence of Buddhism and to the role Buddhism has in the construction of a Hyolmo identity, leading shamans of the community explain it as a return to the correct form of the ransom ritual, where anything red, and not necessarily blood, could be exchanged with non-human entities for the well-being of the human patients.

A second pattern involves a marked shift from orality towards the written dimension. While indigenous religions relied mainly on shamans and singers for the transmission of their repertoires of local lore, mythologies, genealogies and ritual songs, the growth of literacy and the need for standardization has created the mass production of pamphlets, dictionaries and ritual books in mother tongues, often with Nepalese and English translations. Even among Nepalese Buddhist indigenous groups of Tibetan origin (like the Hyolmo and the Sherpa), the textual dimension was mostly linked to orality at the village level, except from few learned lamas; now, numerous members of the population, and especially younger generations, can speak and read Nepali, Tibetan, Hindi and English. Despite standardization, rituals have undergone substantial modifications, either towards simplification or towards increased complexity. For example, I witnessed cases of simplification of shamanic rituals for healing purposes conducted in an urban environment. While the traditional procedure involves all-night séances with constant drumming and animal sacrifice, several religious specialists have adapted to the new context by shortening the length of the ritual or shifting it to diurnal times, wearing less elaborate costumes and in front of simplified temporary altars. Conversely, when performing at collective ethnic festivals, the degree of details is incremented and allegedly matched with the ideal model of the ancient times. Simplification is also seen in the case of new religious movements, where the call for a more or less universalistic religion preached by the Gurus demands individualistic practice detached from traditional temple devotion, clan or kinship ties (Holmberg 2016, 116).

A last point regards the multiplication of fixed ritual spaces. Indigenous religions of marginalized groups of Nepal, especially those relying on shamanic religious specialists, were often characterized by the quasi-absence of permanent religious places, except for specific points of the sacred landscape or the home shrines where the shaman holds his drum and paraphernalia. Recent trends and new contexts seem to favor an increase in localization, with worship places made permanent, like the case of the Kiranti Hattiban shrine in Kathmandu but also the spread of religious specialists' studios, where shamans, healers, and astrologers engage in their activities on a daily basis. Equally relevant is the proliferation of pilgrimage sites and their incorporation into the ritual calendar of the adivasi communities, thus conflating them with the aforementioned ethnic festivals. Pilgrimage sites become lieux de mémoire, where communities gather and express their shared feelings towards the common material and non-material components of their heritage (Nora 1984). Dotting the landscape 
with sacred spots, where a common identity is physically and ritually expressed, mirrors the process of encroachment upon the political space by the marginalized communities, while at the same time mimicking the strategies adopted by the more established religions (Hinduism, Christianity and Islam) during their phases of propagation.

\section{References}

Balikci, Anna. 2008. Lamas, Shamans and Ancestors: Village Religion in Sikkim. Brill's Tibetan Studies Library 17. Leiden: Brill.

Barth, Fredrik. 1969. Ethnic Groups and Boundaries: The Social Organization of Culture Difference. Oslo: Universitetsforlaget.

Berg, Eberhard. 2003. "On Local Festival Performance: The Sherpa Dumji in a World of Dramatically Increasing Uncertainties." European Bulletin of Himalayan Research 25-26: 168204.

Berreman, Gerald D. 1963. Hindus of the Himalayas. Berkeley, CA: University of California Press.

Bhattachan, Krishna B, and Kailash N Pyakuryal. 1996. "The Issue of National Integration in Nepal: An Ethnoregional Approach." Occasional Papers in Sociology and Anthropology 5: 17-38.

Bista, Dor Bahadur. 1967. People of Nepal. Kathmandu: Ministry of Information.

Bourguignon, E. 1976. Possession. San Francisco, CA: Chandler \& Sharp Publishers.

Campbell, Ben. 2013. Living Between Juniper and Palm: Nature, Culture, and Power in the Himalayas. New Delhi: Oxford University Press.

Caplan, Lionel. 1970. Land and Social Change in Easter Nepal: A Hindu Tribal Relationship. Berkeley, CA: University of California Press.

- 1990. "Tribes in the Ethnography of Nepal: Some Comments on a Debate." Contribution to Nepalese Studies 17 (2): 129-45.

Clarke, Graham E. 1980a. "A Helambu History." Journal of the Nepal Research Centre 4: 1-38.

- 1980b. "Lama and Tamang in Yolmo." In Tibetan Studies in Honor of Hugh Richardson, edited by M. Aris and A. S. S. Kyi, 79-86. Warminster: Aris and Phillips.

- 1983. "The Great and Little Traditions in the Study of Yolmo, Nepal." In Contributions on Tibetan Language, History, and Culture, edited by Ernst Steinkellner and Helmut Tauscher, 1:21-37. Vienna: Arbeitskreis für Tibetische und Buddhistische Studien.

— 1985. "Hierarchy, Status and Social History in Nepal." In Contexts and Levels: Anthropological Essays on Hierarchy, edited by Robert Harrison Barnes, Daniel de Coppet, and Robert J. Parkin, 193-210. JASO Occasional Papers 4. Oxford: JASO Occasional Papers. Dasgupta, Sanjukta, and Raj Sekhar Basu, eds. 2012. Narratives from the Margins: Aspects of Adivasi History in India. New Delhi: Primus Books.

Desjarlais, Robert R. 1992. Body and Emotion: The Aesthetics of Illness and Healing in the Nepal Himalayas. Philadelphia, PA: University of Pennsylvania Press.

- 2003. Sensory Biographies: Lives and Deaths Among Nepal's Yolmo Buddhists. Berkeley, CA: University of California Press.

Gaenszle, Martin. 2000. Origins and Migrations: Kinship, Mythology and Ethnic Identity Among the Mewahang Rai of East Nepal. Kathmandu: Mandala Book Point.

- 2002. Ancestral Voices: Oral Ritual Texts and Their Social Contexts Among the Mewahang Rai of East Nepal. Vol. 4. Münster: Lit. 
2016. "Redefining Kiranti Religion in Contemporary Nepal." In Religion, Secularism, and Ethnicity in Contemporary Nepal, edited by David N. Gellner, Sondra L. Hausner, and Chiara Letizia, 150-91. Delhi: Oxford University Press.

Gellner, David N. 1994. "Priests, Healers, Mediums and Witches: The Context of Possession in the Kathmandu Valley, Nepal." Man 29 (1): 27-48.

- 2008. "Ethnicity and Nationalism in the World's Only Hindu State." In Nationalism and Ethnicity in Nepal, edited by David N. Gellner, Joanna Pfaff-Czarnecka, and John Whelpton, 3-31. Kathmandu: Vajra Publications.

- 2009. Ethnic Activism and Civil Society in South Asia. Vol. 2. New Delhi: Sage.

Ghimire, Pustak. 2016. “'Living Goddesses Everywhere?' On the Possession of Women by the Goddess Bhagavati in Some Mountain Villages of Eastern Nepal.” In Religion, Secularism, and Ethnicity in Contemporary Nepal, edited by David N. Gellner, Sondra L. Hausner, and Chiara Letizia, 326-52. Delhi: Oxford University Press.

Gurung, Harka. 2005. "The Dalit Context." Occasional Papers in Sociology and Anthropology 9: $1-21$.

Hawley, John Stratton, and Donna Marie Wulff, eds. 1996. Devi: Goddesses of India. Berkeley, CA: University of California Press.

Hobsbawm, Eric J., and Terence O. Ranger. 1983. The Invention of Tradition. Cambridge, MA: Cambridge University Press.

Holmberg, David H. 1989. Order in Paradox Myth, Ritual and Exchange Among Nepal's Tamang. Ithaca, NY: Cornell University Press.

- 2016. "Tamang Lhochhar and the New Nepal." In Religion, Secularism, and Ethnicity in Contemporary Nepal, edited by David N. Gellner, Sondra L. Hausner, and Chiara Letizia, 302-25. Delhi: Oxford University Press.

Höfer, Andras. 1994. A Recitation of the Tamang Shaman in Nepal. Bonn: VGH Wissenschaftsverlag.

- 2012. The Caste Hierarchy and the State in Nepal: A Study of the Muluki Ain of 1854. Lalitpur: Himal Books.

Hutt, Michael. 2004. Himalayan People's War: Nepal's Maoist Rebellion. Bloomington, IN: Indiana University Press.

Kievelitz, Uwe. 1996. "Ethnicity and Nationalism in the Nepali Context: A Perspective from Europe." Occasional Papers in Sociology and Anthropology 5: 1-16.

Kloppenborg, Ria. 1977. "Theravada Buddhism in Nepal." Kailash 5: 301-21.

Krauskopff, Gisèle, ed. 2009. Les Faiseurs d'histoires: Politique de l'origine et écrits sur le passé. Nanterre: Société d'ethnologie.

Lawoti, Mahendra, and Anup Kumar Pahari, eds. 2009. The Maoist Insurgency in Nepal: Revolution in the Twenty-First Century. Vol. 20. London, UK: Routledge.

Letizia, Chiara. 2014. "Buddhist Activism, New Sanghas, and the Politics of Belonging Among Some Tharu and Magar Communities of Southern Nepal." In Facing Globalization in the Himalayas: Belonging and the Politics of the Self, edited by Gérard Toffin and Joanna PfaffCzarnecka, 286-322. Delhi: Sage.

- 2016. "Ideas of Secularism in Contemporary Nepal." In Religion, Secularism, and Ethnicity in Contemporary Nepal, edited by David N. Gellner, Sondra L. Hausner, and Chiara Letizia, 35-76. Delhi: Oxford University Press.

Leve, Lauren G. 2002. "Subjects, Selves, and the Politics of Personhood in Theravada Buddhism in Nepal." The Journal of Asian Studies 61 (3): 833-60. 
Lewis, Ioan M. 1971. Ecstatic Religion: An Anthropological Study of Spirit Possession and Shamanism. Harmondsworth: Penguin Books.

Martínez Cobo, José R. 1986. Study of the Problem of Discrimination Against Indigenous Populations. New York, NY: United Nations.

Mastromattei, Romano. 1988. La terra reale: Dèi, spiriti, uomini in Nepal. Rome: Levi.

Maybury-Lewis, David. 1997. Indigenous Peoples, Ethnic Groups and the State. Boston, MA: Allyn and Bacon.

Mumford, Stan Royal. 1990. Himalayan Dialogue: Tibetan Lamas and Gurung Shamans in Nepal. Madison, WI: University of Wisconsin Press.

Nora, Pierre. 1984. Lieux de Mémoire. Paris: Gallimard.

Oppitz, Michael. 1974. Geschichte und Sozialordnung der Sherpa. Innsbruck-Munich: Universitatsverlag Wagner.

— 2017. "Analogies, Variations, Chance: Comparing Local Shamanisms." Shaman 25 (1-2): 61-91.

Ortner, Sherry B. 1978. Sherpas Through Their Rituals. Cambridge, MA: Cambridge University Press.

. 1989. High Religion: A Cultural and Political History of Sherpa Buddhism. Princeton, NJ: Princeton University Press.

Pignède, Bernard. 1966. Les Gurungs. Une population himalayenne du Népal. La Haye: Mouton.

Sax, William S., and Helen Basu, eds. 2015. The Law of Possession: Ritual, Healing, and the Secular State. New York, NY: Oxford University Press.

Schmidt, Bettina E., and Lucy Huskinson, eds. 2010. Spirit Possession and Trance: New Interdisciplinary Perspectives. London, UK: Bloomsbury Publishing.

Scott, James C. 1998. Seeing Like a State: How Certain Schemes to Improve the Human Condition Have Failed. New Haven, CT: Yale University Press.

Sharma, Arvind. 2013. “The Religious Another." The Indian Express. October 11, 2013. https: //indianexpress.com/article/opinion/columns/the-religious-another/.

Shneiderman, Sarah. 2015. Rituals of Ethnicity: Thangmi Identities Between Nepal and India. Philadelphia, PA: University of Pennsylvania Press.

Singh, Mahendra Prasad, and Veena Kukreja. 2014. Federalism in South Asia. New Delhi: Routledge.

Smith, Frederick M. 2012. The Self Possessed: Deity and Spirit Possession in South Asian Literature and Civilization. New York, NY: Columbia University Press.

Steinmann, Brigitte. 1987. Les Tamang du Népal: Usages et religion, religion de l'usage. Paris: Editions Recherche sur les civilisations.

Subba, Tanka Bahadur. 1999. Politics of Culture: A Study of Three Kirata Communities in the Eastern Himalayas. Chennai: Orient Blackswan.

Thapa, Deepak, ed. 2003. Understanding the Maoist Movement of Nepal. Vol. 10. Kathmandu: Centre for Social Research and Development.

Toffin, Gérard. 2009. "The Janajati/Adivasi Movement in Nepal: Myths and Realities of Indigeneity." Sociological Bulletin 58 (1): 25-42.

- 2016. "Neither Statues nor Ritual: An Analysis of New Religious Movements and Therapists in Nepal." In Religion, Secularism, and Ethnicity in Contemporary Nepal, edited by David N. Gellner, Sondra L. Hausner, and Chiara Letizia, 115-49. Delhi: Oxford University Press. 
Torri, Davide. 2014. Il Lama E Il Bombo: Sciamanismo E Buddhismo Tra Gli Hyolmo Del Nepal. Vol. 2. Rome: Edizioni Nuova Cultura.

. 2017. "Caring for Ancestral Heritage Away from Home: The Hyolmo Adivasi (Indigenous People) of Helambu in Kathmandu." Material Religion 13 (3): 385-86.

Wettstein, Marion. 2016. "How Ethnic Identity Becomes Real: The Enactment of Identity Roles and the Material Manifestation of Shifting Identities Among the Nagas." Asian Ethnicity 17 (3): 384-99.

Whelpton, John. 2005. A History of Nepal. Cambridge, MA: Cambridge University Press. Zedong, Mao. 1940. On New Democracy. Peking: Foreign Language Press. 